\title{
IMPLIKASI SISTEM PEMILIHAN UMUM INDONESIA
}

\author{
(The Implication of Indonesia Election System)
}

\author{
Marulak Pardede \\ Pusat Penelitian dan Pengembangan Sistem Hukum Nasional \\ Badan Pembinaan Hukum Nasional \\ Jl. Mayjen Sutoyo No. 10 Cililitan Jakarta \\ Email:marulakp@yahoo.com
}

Naskah diterima: 17 Maret 2014; revisi: 14 April 2014; disetujui: 29 April 2014

\begin{abstract}
Abstrak
Dasar hukum pelaksanaan pemilihan umum di Indonesia yang diatur dalam undang-undang, sejak bergulirnya era reformasi sampai saat ini selalu mengalami perubahan. Setiap perubahan undang-undang pemilu selalu dilakukan sebelum penyelenggaraan pemilu dengan alasan sebagai hasil evaluasi penyelenggaraan pemilu pada periode sebelumnya. Perubahan undang-undang pemilu juga selalu dilakukan satu paket perubahan dengan undang-undang penyelenggara pemilu dan undang-undang partai politik, paket perubahan undang-undang ini juga biasa disebut paket perubahan undangundang politik. Kelemahan pada legislasi dan regulasi menyebabkan sejumlah ketentuan yang memunculkan penafsiran berbeda dalam pelaksanaannya. Keputusan Mahkamah Konstitusi yang membatalkan sistem pemilu proporsional terbuka terbatas menjadi terbuka penuh, menunjukan regulasi penyelenggaraan pemilu yang belum sempurna. Melalui pelaksanaan pemilihan umum Dewan Perwakilan Rakyat, Dewan Perwakilan Rakyat Daerah, Dewan Perwakilan Daerah dan Presiden/Wakil Presiden tahun 2014 ini, diharapkan dapat menjadi tumpuan perubahan untuk menjadi lebih baik. Permasalahan yang diteliti adalah bagaimanakah pelaksanaan sistem pemilihan umum di Indonesia; serta bagaimana dampak pelaksanaan sistem pemilihan langsung di Indonesia. Dengan menggunakan metode yuridis normatif dengan analisis data kualitatif disimpulkan bahwa dampak dari sistem pemilihan langsung di Indonesia telah melahirkan tindak pidana korupsi dan politisi korup. Oleh karenanya dimasa mendatang sistem pemilihan umum ini perlu ditinjau ulang.
\end{abstract}

Kata Kunci: Refleksi, Evaluasi, Sistem, Pemilihan Umum

\section{Abstract}

The legal basis for the implementation of election in Indonesia, as outlined in the Law, since the reform era until now, always changing. Any changes to the election law, always made before the election for next period run. And changes in election law justified as evaluation for the election results in the previous period. Changes in election law also always carried as a package of changes to electoral administration law and the law of political parties, commonly this package of changes also called the package of changes in political law. Weaknesses in legislation and regulation led to a number of provisions which is rise different interpretations in its implementation. The Constitutional Court (MK) verdict that cancelled limited open proportional election system to be fully open, shows that election regulations are rudimentary. Through this parliament, the House of Representatives and the President / Vice President election in 2014, we're expect to become the foundation of change for the better election system. The problems need to research are: How does setting of legal basis for the implementation of elections in Indonesia? How does evaluation of election systems in Indonesia? How the implication of implementation election system directly in Indonesia? Using normative juridical method with descriptive type and method of qualitative data analysis can be described the negative impact of election system directly in Indonesia has causing corruption action and corrupt politicians. Therefore, in the future, this election system need to be reviewed.

Keywords: Reflection, Evaluation, System, Election 


\section{A. Pendahuluan}

Pengertian Pemilihan Umum menurut Matori Abdul Djalil, ${ }^{1}$ antara lain adalah memberikan kepastian terhadap alih kepemimpinan dan kekuasaan (transfer of Leader and Power) secara konstitusional untuk melahirkan pemimpin yang legitimatif; Pemilihan umum adalah wujud dari pelaksanaan kedaulatan rakyat (Sovereignty) secara mendasar di negara demokrasi; Pemilihan Umum dimaksudkan sebagai wahana formal untuk membentuk tatanan negara dan masyarakat (State and Social formation) menuju tatanan yang lebih baik; dapat menjadi filter kepercayaan rakyat terhadap partai politik yang menjadi pemikiran rakyat. Sedangkan menurut Syamsudin Haris, menyatakan bahwa Pemilihan Umum adalah ${ }^{2}$ lembaga sekaligus praktek politik yang memungkinkan terbentuknya sebuah pemerintahan perwakilan (Representative Government). Sementara menurut A.S. Hikam, Pemilihan Umum adalah merupakan lembaga dan sekaligus praktek politik yang mempunyai 2 (dua) dimensi, yang dilihat dari luar tampak saling berseberangan. ${ }^{3}$ Pada dimensi pertama, Pemilihan Umum pada umumnya dimengerti sebagai sarana bagi perwujudan keadulatan rakyat dan sarana artikulasi kepentingan warga negara untuk mewujudkan wakil-wakil mereka. Sedangkan pada dimensi kedua, yang ada pada Pemilihan Umum yaitu sebagai salah satu sarana untuk memberikan dan memperkuat legitimasi politik pemerintah, sehingga keberadaannya, kebijaksanaan, dan program-program yang dibuatnya dapat diwujudkan dengan lebih mudah dan mempunyai ikatan sanksi yang kuat.

Pentingnya dilaksanakan Pemilihan Umum pada dasarnya adalah untuk melaksanakan kedaulatan rakyat; memilih wakil-wakil rakyat; meyakinkan atau setidak-tidaknya memperbaharui kesepakatan pihak warga negara; mempengaruhi perilaku warga negara; dan mendidik penguasa untuk semakin mengandalkan kesepakatan (consent) dari rakyat ketimbang pemaksanaan (caercion) untuk mempertahankan legitimasinya.

Beberapa waktu lalu Mahkamah Konstitusi (MK) mengabulkan permohonan Effendi Gazali dan kawan-kawan tentang pemilu yang dilakukan serentak, baik pemilihan anggota legislatif (Pileg) dan Pemilihan Presiden (Pilpres). ${ }^{4}$ Namun demikian MK menyatakan bahwa putusan ini baru mulai berlaku untuk Pemilu 2019 dan seterusnya. MK menilai proses pemilu 2014 sedang berjalan sehingga dikhawatirkan mengganggu penyelenggaraan pemilu yang sedang berlangsung jika langsung dilaksanakan. $^{5}$

Dengan demikian akan terjadi perubahan peraturan Pemilihan Umum (Pemilu) di Indonesia. Ini berarti bahwa dasar hukum

1 Matori Abdul Djalil, Tuntutan Reformasi dan Penyelenggaraan Pemilu 1999 dalam Masa Transisi (Jakarta: KIPP, 1999), hlm. 33-35.

Syamsudin Haris, Menggugat Pemilihan Umum Orde Baru (Jakarta: Yayasan Obor Indonesia, 1998), hlm. 7.

Muhammad A.S. Hikam, Pemilu dan Legitimasi Politik (Jakarta: Yayasan Obor Indonesia, 1998), hlm. 49-50.

4 Rini Friastuti, "Putusan MK: Pemilu Serentak Untuk Pemilu 2019", detik News, http://news.detik.com/ read/ 2014/ 01/ 23/ 151205/ 2476095 /10/ putusan-mk-pemilu-serentak- untuk- pemilu-2019?ntprofil, (diakses tanggal 23 Januari 2014).

5 Dalam putusan ini, Hakim Konstitusi Maria Farida Indarti memilih berbeda pendapat dan menolak permohonan untuk seluruhnya. Pasal 3 ayat (5) Undang-Undang Pemilihan Presiden yang digugat Effendi Gazali, serta menyatakan Pemilu Presiden dan Wakil Presiden dilaksanakan setelah pelaksanaan pemilihan umum anggota DPR, DPD dan DPRD. 
pelaksanaan Pemilu di Indonesia sejak bergulirnya era reformasi sampai saat ini, selalu mengalami perubahan. Sejak tahun 1999, undang-undang pemilu yang berlaku tercatat telah mengalami empat kali perubahan hingga kini. Diantaranya adalah Undang-Undang Nomor 3 Tahun 1999, Undang-Undang Nomor 12 Tahun 2003, Undang-Undang Nomor 10 Tahun 2008, dan perubahan terakhir UndangUndang Nomor 8 Tahun 2012. Setiap perubahan undang-undang pemilu, selalu dilakukan sebelum penyelenggaraan pemilu dilakukan. Perubahan undang-undang ini selalu beralasan karena hasil evaluasi penyelenggaraan pemilu pada periode sebelumnya. Perubahan undangundang pemilu juga selalu dilakukan satu paket perubahan dengan undang-undang penyelenggara pemilu dan undang-undang partai politik, paket perubahan undang-undang ini juga biasa disebut paket perubahan undangundang politik. Pembahasan legislasi undangundang pemilu di Dewan Perwakilan Rakyat (DPR), oleh sementara kalangan dipandang selalu berdasarkan kepentingan partai politik, fraksi, maupun pemerintah dan menjadi produk kesepakatan kepentingan dari pihak-pihak tertentu saja. Padahal, semestinya pembahasan undang-undang pemilu ini bertujuan agar masyarakat sipil juga dapat memberikan respon, pendapat, rekomendasi, dan mengingkatkan para pemegang kekuasaan untuk memikirkan pula kepentingan masyarakat Indonesia secara luas.

Kelemahan pada penyelenggaraan pemilu ini tercermin dari munculnya berbagai permasalahan pada pengaturan jangka waktu (time schedule) tahapan penyelenggaraan
Pemilu, verifikasi peserta Pemilu, verifikasi daftar calon legislatif, tahap pemungutan suara, tahap penghitungan suara, dan penetapan calon legislatif terpilih. Selain itu terdapat fakta bahwa terjadi peningkatan angka korupsi dalam pelaksanaan pemilu di Indonesia, termasuk pelaksanaan pemilihan Kepala Daerah.

Berdasarkan evaluasi Kementerian Dalam Negeri (Kemendagri) sejak 2005 hingga akhir Mei 2013, sebanyak 294 Kepala daerah tersandung tindak pidana korupsi, dan diperkirakan akhir tahun 2013 ini akan melewati 300 orang. Mereka yang terlibat adalah, 21 orang Gubernur, 7 wakil gubernur, 156 Bupati, 46 wakil bupati, 41 walikota dan 20 wakil walikota. Sekedar menyebut contoh yang terkini, diantaranya: Gubernur Sumatera Utara, Sjamsul Arifin; Gubernur Riau, Rusli Zainal; Gubernur Bengkulu, Agusrin Najamudin; Gubernur Maluku Utara, Thaib Armaiyn; Gubernur Kalimantan Timur, Awang Faoek Ishak; Walikota Salatiga, John Manuel Manoppo; Walikota Palopo, Andi Tendriajieng; Bupati Kepulauan Aru, Theddy Tengko; Bupati Subang, Eep Didayat, Bupati Lampung Timur, Satono; Bupati Buol, Amran Batalipu; Bupati Mandailing Natal, Hidayat Batubara, dan sederet nama lainnya. Semua nama-nama tersebut, pada awal pemilihannya diajukan oleh organisasi partai politik sesuai dengan Pasal 12 Undang-Undang Nomor 2 Tahun 2008 tentang Partai politik. ${ }^{6}$

Keadaan ini sangat berkaitan erat dengan efek negatif pilihan bangsa Indonesia dalam menentukan sistem pemilihan langsung, sebagaimana diatur dalam Pasal 2 UndangUndang Nomor 10 tahun 2008 tentang Pemilu, yang menjadikan kepala daerah membutuhkan

Koran Seputar Indonesia (SIND0), "Ratusan Kepala daerah Terjerat Korupsi", Senin, 3 Juni 2013, hlm. 8-9. 
biaya yang sangat besar, sehingga begitu terpilih dan berkuasa, terjebak melakukan tindakan yang bertentangan dengan hukum, manipulasi, korupsi, kolusi dan nepotisme (KKN) serta berbagai perbuatan tercela lainnya. Biaya politik yang sangat besar membuat kepala daerah kehilangan logika berfikir yang sehat. Tidak bisa lagi memikirkan pembangunan dan pertumbuhan ekonomi untuk kesejahteraan rakyat banyak, tetapi hanya memikirkan bagaimana secepatnya menghasilkan uang untuk mengembalikan modal, membayar utang kepada para sponsor, dan menyetor ke partai politik pengusungnya.

Beraneka ragam modus maupun bentuk praktik pelaksanaan korupsi melalui organisasi partai politik, diantaranya adalah mengutakutik APBN/D, mempermainkan harga proyek/kegiatan digelembungkan (mark-up), memainkan sektor pengadaan barang dan jasa, memainkan proses pemberian perizinan usaha dan tambang pengelolaan sumber daya, pertanggungjawaban keuangan fiktif, pelaksanaan tender, dan berbagai manipulasi kegiatan lainnya. Modus korupsi politik ini, umumnya terencana, bahkan terasa ada unsur koordinasi dalam sebuah kasus korupsi politik. Koordinasi itu melibatkan politisi yang berkedudukan baik itu di eksekutif maupun legislatif. Kasus-kasus korupsi ini terlihat terencana, terkoordinasi dan dirancang dengan baik. Hal ini terlihat dari mulai perencanaan yang dilakukan sejak awal, di mana ada komunikasi antara politisi legislatif, birokarasi eksekutif serta juga ada pembicaraan dengan pelaksana tender. Trend kejahatan korupsi politik ini, akan semakin menggurita, mengingat pada tahun 2014 adalah pementasan pesta demokrasi 250 juta rakyat Indonesia. Sehingga praktis, Tahun 2014 ini, partai-partai politik akan mengoptimalkan mesin pengumpul uang dengan cara melegalkan cara-cara koruptif, serta melakukan intervensi yang melanggar hukum terhadap proses politik (IIlegal intervention in the public process), terutama dalam konteks pengambilan kebijakan publik oleh pemerintah.

\section{B. Permasalahan}

Berdasarkan uraian tersebut di atas, maka permasalahan yang diteliti dapat dikemukakan sebagai berikut, yaitu:

Bagaimanakah pelaksanaan sistem pemilihan umum di Indonesia?

Apakah dampak negatif pelaksanaan sistem pemilihan langsung di Indonesia?

\section{Metode Penelitian}

Metode pendekatan yang dipergunakan dalam pelaksanaan penelitian ini adalah bersifat yuridis normatif. Sejalan dengan maksud dan tujuan penelitian yang ingin dicapai, maka tipe penelitian ini adalah deskriptif, yaitu memberikan gambaran secermat mungkin mengenai obyek penelitian dengan pemilihan bahan yang representatif. Tipe perencanaan penelitian adalah penelitian hukum normatif, dalam pengertian sebagaimana dimasudkan oleh Soerjono Soekanto dan Sri Mamuji, yaitu penelitian yang meliputi asas-asas hukum, sinkronisasi hukum dan perbandingan hukum. ${ }^{7}$ 
Adapun bahan-bahan penelitian yang dipergunakan dalam penelitian ini adalah:

1. Bahan Primer, yang mencakup peraturan perundang-undangan yang berlaku, yurisprudensi yang berkaitan dengan pokok permasalahan penelitian.

2. Bahan Sekunder, terdiri dari hasil-hasil penelitian yang telah ada sebelumnya yang terkait dengan permasalahan penelitian; kepustakaan, termasuk bahan dan hasil seminar dan konferensi-konferensi serta ulasan mass-media, termasuk ulasan dalam majalah hukum, majalah populer dan surat kabar yang berkaitan dengan objek penelitian;

3. Bahan Tersier, yang terdiri dari kamus hukum, ensiklopedi dan kamus pendukung lainnya.

Alat Penelitian yang dipergunakan dalam penelitian ini adalah studi kepustakaan/ Normatif (Library Studies), yaitu mempelajari berbagai literatur yang berhubungan dengan objek penelitian, termasuk penelitian normatif mengenai peraturan perundang-undangan yang berhubungan dengan penelitian, serta studi dokumen (documentary studies) dari bahan primer dan sekunder. Sedangkan metode analisis data yang dipergunakan dalam penelitian ini adalah kualitatif. Data yang berupa angka sedapat mungkin disajikan dalam bentuk angka. Sifat dan Bentuk Laporan penelitian ini, adalah Deskriptif-analitis.

\section{Pembahasan}

\section{Evaluasi Pelaksanaan Sistem Pemilihan Umum}

Secara garis besar, sistem Pemilihan Umum dibagi kedalam 2 (dua) formula, yaitu sistem proporsional dan distrik. Namun secara empirik, banyak negara yang menerapkan kombinasi dari kedua sistem ini sehingga melahirkan beberapa variasi sistem Pemilihan Umum. ${ }^{8}$ Sistem proporsional (Proportional Representation System) --yang dianut di Indonesia dengan beberapa modifikasi-- pada dasarnya menganut prinsip bahwa setiap pemilih mempunyai satu suara dan setiap anggota parlemen mewakili jumlah penduduk tertentu. ${ }^{9}$ Sisa suara dalam setiap daerah pemilihan tidak hilang tetapi dapat digabung dengan jumlah suara dari partai yang sama, meskipun suara tersebut diperoleh dari daerah pemilihan yang berlainan. Setiap partai politik akan memperoleh kursi di parleman secara proporsional dengan perolehan suara yang didapat. Dengan sistem ini, partai-partai kecil masih mungkin memperoleh kursi di lembaga legislatif. Sistem ini banyak diterapkan pada negara-negara yang mempraktikkan demokrasi, seperti di Amerika Latin, Amerika, dan beberapa negara di Eropa Barat, seperti Austria, Bulgaria, Denmark, Finlandia, Swedia, dan Swiss. Argumentasi dari penerapan sistem proporsional adalah kenyataan bahwa dalam sistem ini perolehan suara dalam suatu partai secara nasional berbanding langsung dengan perolehan kursi yang diperoleh di lembaga

8 J. Kristiadi, "Sistem Pemilu: Proporsional, Distrik atau Campuran" (makalah disampaikan pada Dialog Nasional tentang "Agenda Pemilu: Visi, Tantangan dan Prospek", Depok, 20-21 Juli 1998) hlm. 2.

$9 \quad$ Ibid., hlm. 3 
legislatif. ${ }^{10}$ Sistem ini mempunyai beberapa variasi, yaitu: Single Transverable Vote System (STV); List Proportional Representation System (List PR); dan Mixed Member Proportional System (MMP).

Sebagai salah satu sarana untuk berpartisipasi, partai politik mempunyai beberapa fungsi, yaitu sebagai sarana komunikasi politik, perumusan atau artikulasi kepentingan, penggabungan atau agregasi kepentingan, rekrutmen politik, dan sebagai sarana pengatur konflik. Melalui fungsi-fungsinya tersebut partai politik menjadi jembatan antara yang memerintah dan yang diperintah. Namun sering terdapat gejala bahwa pelaksanaan fungsi partai sebagai jembatan, sengaja atau tidak sengaja, kurang dapat terlaksana, sehingga menimbulkan kegelisahan di dalam masyarakat. Keadaan itu tentu saja dapat menghambat berkembangnya kehidupan politik yang sehat.

Sejak tahun 1999, undang-undang pemilu yang berlaku tercatat telah mengalami empat kali perubahan hingga kini. Diantaranya adalah UU No. 3 Tahun 1999, UU No. 12 Tahun 2003, UU No. 10 Tahun 2008, dan perubahan terakhir UU No. 8 Tahun 2012. Setiap perubahan undangundang pemilu, selalu dilakukan sebelum penyelenggaraan pemilu dilakukan. Perubahan undang-undang ini selalu beralasan karena hasil evaluasi penyelenggaraan pemilu pada periode sebelumnya. Evaluasi atas beberapa kelemahan pada penyelenggaraan pemilu ini di samping tercermin dari munculnya berbagai permasalahan pada pengaturan jangka waktu (time schedule) tahapan penyelenggaraan
Pemilu, verifikasi peserta Pemilu, verifikasi daftar calon legislatif (caleg), tahap pemungutan suara, tahap penghitungan suara, dan penetapan calon legislatif terpilih, juga terkait dengan fungsi dari partai politik itu sendiri.

Partai politik seharusnya menjalankan pula fungsi sebagai sarana sosialisasi politik, yakni suatu proses dimana seseorang memperoleh pandangan, orientasi dan nilai-nilai dari masyarakat dimana dia berada. Termasuk di dalamnya proses pewarisan norma dan nilai dari suatu generasi ke generasi berikutnya. Sedangkan melalui fungsinya sebagai sarana rekrutmen politik, partai mencari anggota baru dan mengajak orang yang berbakat untuk berpartisipasi dalam proses politik. Dengan didirikannya organisasi-organisasi massa yang melibatkan golongan-golongan buruh, petani, pemuda, mahasiswa, wanita dan sebagainya, kesempatan untuk berpartisipasi diperluas. Rekruitmen politik menjamin komunitas dan kelestarian partai sekaligus merupakan salah satu cara untuk menyeleksi calon-calon pemimpin.

Menurut Liddle, suatu pemerintahan yang demokratis, efektif, dan stabil memerlukan partaipartai politik yang melalui proses Pemilihan Umum yang luber; terbebas dari kekuatan lain khususnya penguasa-penguasa pribadi, birokrat atau militer; mempunyai dukungan yang luas dari masyarakat; dan mengandalkan pada kepemimpinan yang dipercaya oleh anggotanya. ${ }^{11}$ Namun seperti kita ketahui, partaipartai politik hasil fusi di bawah Orde Baru adalah partai yang sudah kehilangan momentumnya sebagai partai, akibat introduksi kebijakan 
depolitisasi, deparpolisasi, dan deideologi yang amat intens sejak awal Orde Baru. Partai politik bukan lagi perpanjangan kepentingan dan aspirasi masyarakat, sebab negara telah menjadi satu-satunya sumber rujukan dan legitimasi bagi partai, baik dalam nenentukan asas, membuat program, memilih ketua umum, menentukan calon (dan kemudian menariknya kembali dari DPR), maupun dalam mengartikulasikan dan mengagregasikan kepentingan masyarakat. ${ }^{12}$ Beberapa waktu yang lalu, partai politik gagal mengemban misinya akibat campur tangan pemerintah dalam penentuan Ketua Umum Orpol menjadi tidak mandiri, serta menghasilkan suatu tatanan yang semu, yakni suatu situasi dimana partai politik itu "antara ada dan tiada". Partai politik gagal menjalankan fungsi-fungsinya. Partai hanya sibuk menjelang Pemilihan Umum, pendidikan politik yang semestinya menjadi tugas partai politik, diambil alih dan dimonopoli oleh pemerintah. Rekruitmen kepemimpinan tidak lagi berlangsung dan elit organisasi politik menjadi lebih oportunistik, sementara mekanisme umpan balik yang sehat dari masyarakat tidak pernah berlangsung.

Pendidikan politik bagi masyarakat didominasi oleh negara, sementara partai politik kehilangan momentumnya antara lain karena ketiadaan anggaran maupun kendala kepengurusan yang hanya sampai ke tingkat cabang. Partai politik sebagai salah satu penyalur aspirasi politik dalam perkembangannya terlihat semakin sulit. Sejak penerimaan asas tunggal oleh semua partai politik dan organisasi kemasyarakatan, sesungguhnya pemerintah memiliki inisiatif yang besar dalam mengendalikan kehidupan politik, sebab setelah itu partai nampak kesulitan dalam merumuskan identitasnya. Jika dibandingkan dengan undangundang Pemilihan Umum sebelumnya, maka undang-undang Pemilihan Umum sekarang ini sudah merupakan kemajuan yang besar. Undangundang Pemilihan Umum Nomor 12 tahun 2003 telah mampu menangkap, menampung, dan mengaspirasikan gagasan berpolitik, gagasan berserikat dan berkumpul serta berpendapat, dan tampaknya semua pihak juga terlibat dengan penyelenggaraan Pemilihan Umum. Hal lain juga dapat dilihat dari setiap parpol yang dapat terlibat dalam penyelenggaraan Pemilihan Umum dengan menjadi Anggota Komisi Pemilihan Umum (KPU) sampai pada tingkat tempat pemungutan suara (TPS). Namun demikian undang-undang ini tentu saja belum semuanya secara maksimum mampu mengakomodasikan aspirasi rakyat.

Pendidikan akan pentingnya pemilu kepada masyarakat harus dilakukan oleh segenap elemen bangsa yang berkompeten di bidangnya, termasuk para akademisi. Karena dengan munculnya kesadaran berpolitik yang bersih, politik uang dalam pelaksanaan kampanye dapat ditekan serendah mungkin. Masyarakat menjadi paham bahwa jika mereka salah dalam memilih pemimpin, selama lima tahun pula mereka akan hidup dalam kesusahan dan kesengsaraan. Praktek korupsi di Indonesia tidak hanya dilakukan para politisi, tetapi ada peran serta pelaku ekonomi untuk memuluskan praktek korupsi tersebut. Munculnya korupsi karena adanya kerja sama antara politisi, penguasa ekonomi, dan birokrasi. Perputaran

12 Samsudin Haris "Perbandingan Pemilu-Pemilu Orde Baru 1971-1992: beberapa catatan Kritis dan Proyeksi", dalam J Kristiadi, ed., Menyelenggarakan Pemilu yang Luber dan Jurdil (Jakarta: CSIS, 1977). 
uang lebih banyak di ranah para penguasa ekonomi atau pengusaha. Oleh karena itu, untuk meminimalisasi tindak korupsi, diperlukan para pengusaha yang jujur dalam menjalankan profesinya, juga tidak menjalankan praktek korupsi dalam mempermudah urusan bisnisnya. Korupsi tidak akan pernah terjadi jika tidak ada niat dan kesempatan. Harus diyakini bahwa dengan berbagai hal yang telah dilakukan oleh segenap komponen bangsa ini dalam memberantas korupsi, suatu saat korupsi di negara ini akan dapat dikurangi secara siginifikan sehingga clean and good goverment dapat terwujud.

Dengan dasar itulah Undang-Undang Politik tahun 2003 saat itu paling tidak sudah memenuhi standar minimum untuk penyelenggaraan sebuah Pemilihan Umum yang demokratis, jujur, dan adil yang diakui berdasarkan standar internasional. Dikatakan standar minimum dan bukan standar ideal karena komponenkomponen untuk sebuah Pemilihan Umum yang jujur dan adil sudah tersedia dan undang-undang itu sendiri juga sudah membuka kesempatan untuk itu.Kelemahan lain juga terlihat dalam pengaturan terkait keberadaan dan kewenagan Komisi Pemilihan Umum (KPU) dalam UndangUndang Nomor 31 Tahun 2002 tentang Partai Politik. Pada saat itu masih dipersoalkan oleh beberapa partai politik yang merasa telah dikurangi kekuasaan mereka untuk menentukan apakah Pemilihan Umum itu sah atau tidak sah dengan adanya aturan bahwa hasil penghitungan suara akan sah apabila ditandatangani oleh $2 / 3$ anggota KPU. Dengan demikian apabila $1 / 3$ plus satu anggota KPU tidak mau menandatangani maka hasil penghitungan suara menjadi tidak sah. Persoalannya adalah, tidak mungkin membiarkan hasil Pemilihan Umum itu disandera oleh $1 / 3$ plus satu anggota KPU, tanpa alasan yang jelas. Oleh karena itu, harus ada cara mengatasi dead lock. Jikalau belum cukup aturan undang-undang, maka akan diatur oleh Peraturan Pemerintah sesuai dengan kebutuhan. Di situlah ada Panitia Pengawas (Panwas) yang difungsikan menjadi arbiter apabila ada yang menyatakan keberatan. Keberatan tertulis itu secara rinci kemudian diserahkan kepada Panwas dan KPU. Panwas dalam tujuh hari meneliti keberatan itu dan kemudian memberikan keputusan. maka apabila keberatan itu ditolak, karena tidak mempunyai alasan yang jelas, maka tanpa ditandatangani pun hasil penghitungan suara itu dianggap sah.

Dalam undang-undang tersebut Panwas disebut juga sebagai lembaga yang menyelesaikan perselisihan. Dalam hal ini ada perselisihan, ada yang ingin menandatangani dan ada yang tidak, maka silahkan mengajukan keberatan. Semua ini adalah hal yang sah menurut undang-undang dan patut menuntut etika politik. Persoalan diatas, di mana beberapa anggota KPU wakil partai politik yang kurang mendapatkan dukungan suara menyatakan penolakan dan keberatan untuk mendatangani hasil Pemilihan Umum, kemudian berlanjut pada penilaian dari tokohtokoh maupun dari publik, sebaiknya mereka mundur dari KPU, karena keberadaannya tidak bisa mewakili masyarakat banyak. Meski jabatan sebagai anggota KPU adalah empat tahun, namun terjadi perbedaan penafsiran. Bagaimana dengan partai-partai dibawah dua persen? Walaupun dalam Undang-undang disebutkan empat tahun, tetapi juga harus diperhatikan ayat lain dalam Undang-undang yang menyatakan bahwa yang menjadi anggota KPU adalah wakilwakil dari partai peserta Pemilihan Umum dan wakil dari pemerintah. Dan pada ayat lain mengatakan bahwa, partai-partai yang hasil perolehan suaranya tidak mencapai dua persen, partai tersebut tidak lagi dapat menjadi peserta 
Pemilihan Umum pada Pemilihan Umum berikutnya.

Konteks empat tahun tersebut harus dilihat konteks ketika masih menjadi wakil peserta Pemilihan Umum, sehingga jika tidak menjadi lagi peserta Pemilihan Umum pada empat tahun berikutnya otomatis kriteria itu gugur. Kelemahan pengaturan dalam Undang-undang Nomor 10 Tahun 2008 yang antara lain meliputi: Ketentuan tentang sistem Pemilu yang menggunakan sistem proporsional terbuka (Pasal 5 ayat (1) Undang-Undang Nomor 10 Tahun 2010, tidak konsisten dengan ketentuan penetapan calon terpilih yang menetapkan kuota 30 persen dari Bilangan Pembagi Pemilihan (BPP). Hal ini dinilai menimbulkan ketidakadilan sehingga digugat dan dibatalkan oleh Mahkamah Konstitusi. Ketentuan tentang pemutakhiran data pemilih, khususnya terkait jangka waktu pengumuman Daftar Pemilih Sementara (DPS), masa perbaikan dan penyusunan Daftar Pemilih Tetap (DPT) terlalu singkat sehingga dalam praktek tidak mencukupi untuk perbaikan dan akurasi. Ketentuan tentang batas kursi dalam suatu Daerah Pemilihan (Dapil) DPR-RI paling sedikit 3 dan maksimal 10 kursi, belum sepenuhnya dapat mendorong keterwakilan karena dalam prakteknya dapat mencakup daerah yang sangat luas (terdiri atas beberapa kabupaten) terutama di luar Jawa, sehingga dapat terjadi satu propinsi hanya satu Dapil. Ketentuan tentang batas kursi dalam suatu Daerah Dapil untuk DPRD Propinsi dan DPRD Kabupaten/Kota tidak sepenuhnya dapat diterapkan karena dalam praktek dapat terjadi karena jumlah penduduk yang sangat besar sehingga satu Dapil dapat melebihi jumlah kursi maksimal di atas 12 kursi. Ketentuan tentang penetapan jumlah kursi dalam satu Dapil DPRD Propinsi yang menegaskan bahwa jumlah kursi setiap Dapil anggota DPRD Propinsi ditetapkan sama dengan Pemilu sebelumnya (Pasal 24 ayat (2) Undang-Undang Nomor 10 Tahun 2008).

Ketentuan ini berpotensi bertentangan dengan ketentuan dalam Pasal 25 ayat (3) yang menentukan dalam hal terjadi pembentukan provinsi baru setelah Pemilu dilakukan penataan Dapil di Provinsi induk sesuai dengan jumlah penduduk. Dengan demikian tidak mungkin Dapil tetap, karena jika ada pemekaran pasti ada pengurangan jumlah penduduk yang berdampak pada berubahnya Dapil. Ketentuan yang mengatur penetapan kursi daerah pemilihan bagi anggota DPRD propinsi agar disesuaikan dengan penetapan kursi daerah pemilihan anggota DPR-RI karena jumlah dan nama kabupaten/kotanya sama, sering terjadi kesulitan ketika dimplementasikan karena untuk beberapa daerah jika disamakan daerah pemilihannya akan menabrak ketentuan batas jumlah kursi dalam sutau daerah pemilihan yang telah ditentukan antara 3-12 kursi (Pasal 314 ayat (1) Undang-Undang Nomor 10 Tahun 2010). Hal ini terjadi karena untuk menetapkan alokasi kursi tiap daerah pemilihan anggota DPRD propinsi didasarkan atas bilangan pembagi penduduk (BPP) dan BPP penduduk tersebut diperoleh dari hasil bagi total jumlah total jumlah penduduk di propinsi tersebut dengan jumlah kursi DPRD propinsi yang sudah secara pasti ditentukan yaitu paling sedikit 35 kursi dan paling banyak 100 kursi (Pasal 23 Undang-Undang Nomor 10 Tahun 2010).

Ketentuan syarat bagi calon anggota legislatif (caleg) khususnya mengenai pemenuhan syarat calon tidak pernah dijatuhi pidana penjara berdasarkan putusan pengadilan yang telah mempunyai kekuatan hukum tetap karena melakukan tindak pidana yang diancam dengan pidana penjara 5 (lima) tahun atau lebih 
(Pasal 12 huruf g dan Pasal 51 ayat (1) huruf g Undang-Undang Nomor 10 Tahun 2010) perlu menyesuaikan dengan semangat Putusan Mahkamah Konstitusi Nomor 4/PUU-VII/2009. Pada intinya yang dilihat dalam pemenuhan syarat calon memenuhi 5 tahun atau lebih adalah ancaman pidana yang sudah pasti yang menjadi dasar pengenaan dakwaan. Ketentuan pencalonan anggota legislatif khususnya mengenai syarat keterwakilan perempuan minimal 30 persen yang diajukanoleh Parpol peserta Pemilu Anggota DPR/DPRD dalam pelaksanaannya sulit dipenuhi. Parpol sering beralasan sulit memenuhi karena keterbatasan dan kekurangsiapan kader perempuan. Hal ini perlu diperjelas mengani sanksi jika Parpol tidak memenuhi kuota caleg perempuan apakah sanksi adminstratif atau sanksi lainya. Ketentuan pemberian suara yang hanya membolehkan pemilih yang terdaftar dalam DPT yang dapat menggunakan hak pilihnya banyak mengakibatkan hilangnya hak pilih warga masyarakat. Hal ini terjadi karena pendaftaran pemilih tidak berjalan sebagaiman mestinya. Ketentuan tentang teknis pemberian suara, dengan memberikan tanda dan kemudian didalam prakteknya diakui berbagai tanda yang dianggap sah menyulitkan warga sehingga banyak suara yang tidak sah. Ketentuan tentang peserta Pemilu Tahun 2004 yang dapat mengikuti Pemilu Pada Tahun 2009, yang ditentukan hanya Parpol yang memiliki kursi di DPR dinilai diskrimintaif dan kemudian dibatalkan oleh Mahkamah Konstitusi. Ketentuan tentang perhitungan pengkategorian sisa suara dan sisa kursi dalam suatu Dapil tidak jelas sehingga menimbulkan multi tafsir dan sengketa di Mahkamah Agung maupun di Mahkamah Konstitusi. Ketentuan tentang pembatasan pengumuman hasil survei oleh lembaga survei publik terkait persepsi masyarakat terhadap peserta Pemilu dianggap membatasi dan tidak sejalan dengan nilai-nilai dalam konstitusi sehingga digugat dan kemudian dibatalkan oleh Mahkamah Kosntitusi. Ketentuan kampanye bagi parpol peserta Pemiluyang telah ditetapkan sebagai peserta Pemilu yaitu 3 (tiga) hari setelah penetapan peserta Pemilu tidak secara tegas mengartu bentuk-bentuk dan media apa saja yang digunakan dalam kampanye dan apa sanksinya jika melanggar ketentuan bentuk dan waktu kampanye. Hal ini terkait dengan ketentuan sanksi kampanye hanya berlaku bagi kampanye terbuka (rapat umum). Ketentuan ambang batas 2,4 persen perolehan suara sah Parpol secara nasional untuk menetapkan Parpol peserta Pemilu yang dapat diikutkan dalam penghitungan.

\section{Dampak Negatif Sistem Pemilihan Langsung}

Semakin meningkatnya kejahatan korupsi yang melibatkan para politisi baik di legislatif, eksekutif maupun yudikatif akhir-akhir ini, sangat berkaitan erat dengan dampak negatif pilihan bangsa Indonesia dalam menentukan sistem pemilihan langsung, sebagaimana diatur dalam pasal 2 Undang-Undang Nomor 10 Tahun 2008 tentang Pemilu, yang menjadikan kepala daerah membutuhkan biaya yang sangat besar, sehingga begitu terpilih dan berkuasa, terjebak melalukan tindakan yang bertentangan dengan hukum, manipulasi, korupsi, kolusi dan nepotisme (KKN) serta berbagai perbuatan tercela lainnya. Biaya politik yang begitu sangat besar, membuat mereka hanya memikirkan bagaimana secepatnya menghasilkan uang untuk mengembalikan modal, membayar utang kepada para sponsor, menyetor ke partai politik pengusungnya. 
Undang-Undang Dasar 1945 dan Perubahannya menetapkan bahwa Negara Kesatuan Republik Indonesia adalah Negara Hukum (State's Law) bukan Negara Kekuasaan (State's Power). Salah satu ciri negara berdaulat adalah ia memiliki kekuasaan (yurisdiksi) untuk menegakan hukum dalam batas wilayah kekuasaannya (hak ekslusif negara). Hak ekslusif Negara dilandaskan pada prinsip State souvereignty, yang meliputi: Equality of states; Territorial intergrity; Non-intervention. ${ }^{13}$ Menurut Mochtar Kusumaatmadja, ${ }^{14}$ pencetus ide hukum pembangunan, telah mengingatkan sejak awal bahwa, terdapat perbedaan yang signifikan antara kedua pengertian istilah tersebut. Kekeliruan sebagaimana dikhawatirkan di atas telah terjadi ketika Negara memaksakan kehendaknya melalui perundangundangan kepada rakyatnya tanpa sistem "check and balances" sehingga menimbulkan efek negatif baik secara sosial, ekonomi, budaya dan politik. Setiap produk peraturan perundang-undangan harus menampakkan filosofi dan misi yang bertujuan menciptakan ketertiban, kepastian hukum dan keadilan serta kemanfaatannya termasuk akibat sosial, ekonomi dan politik pembentukan peraturan perundang-undangan tersebut. Sebagai contoh, untuk mewujukan pemberantasan tindak pidana korupsi telah dilakukan empat kali perubahan UU yang mengandung misi penghukuman (filsafat retributif) dan menyelamatkan keuangan negara (filsafat utilitarianisme) secara bersamaan. Misi yang diemban uu tersebut adalah agar pelaku jera dan negara tidak dirugikan. Namun dalam praktik, filosofi dan misi tersebut sering diabaikan antara lain hanya ditujukan pada penghukuman seberat-beratnya tanpa mempertimbangkan peningkatan pemasukan keuangan negara atau bahkan efek jera tidak lebih meningkat dari sebelum berlakunya empat kali perubahan undangundang tersebut. ${ }^{15}$

Kekuasaan politik berdasarkan UUD 1945, kekuasaan presiden tidak hanya berada di bidang eksekutif semata, tetapi juga ada yang berada dalam bidang legislatif dan yudikatif. Sebagai contoh besarnya peran prsiden dalam meproduksi undang-undang; adanya kekuasaan presiden untuk memberi grasi, amnesti, abolisi dan rehabilitasi. Dan kekuasaan tersebut jelas

13 Perkembangan perpolitikan Negara Kesatuan Republik Indonesia (NKRI) mengalami pasang surut sejak kemerdekaan sampai saat ini yang tidak lain karena pengaruh perkembangan politik global dan dampaknya terhadap sistem pemerintahan, disamping konflik-konflik internal yang telah terjadi sejak era tahun 1950-an sampai saat ini. Politik hukum era pembangunan nasional sejak Tahun 1973 dan dalam GBHN Pelita II Bab 27 telah menganut kebijakan Hukum sebagai sarana pembaharuan masyarakat, law as a tool of social engineering, disesuaikan dan kondisi sosial dan politik yang berkembang memasuki era pembangunan nasional. Disayangkan bahwa dalam praktik, kebijakan hukum pemegang kekuasaan telah memahami secara keliru model hukum pembangunan, khusus kalimats arana yang disamakan dengan alat (tools).

14 Mochtar Kusumaatmadja, Hukum, Masyarakat, dan Pembangunan (Bandung: Binacipta, tanpa tahun).

15 Praktik pembentukan hukum sebagai alat, bukan sarana pembaharuan tampaknya masih terus akan terjadi dalam peta politik hukum di Indonesia, dan hal ini sangat mengkhawatirkan dilihat dari sudut bukan hanya dari aspek perlindungan HAM tersangka dan terdakwa sesuai dengan Bab XA UUD 1945, melainkan juga dari aspek pendidikan hukum generasi bangsa kedepan. Fenomena penguatan hukum sebagai alat tersebut perlu diimbangi dengan kekuatan pers bebas dan bertanggung jawab. Pengawasan eksternal berasal dari kekuatan lembaga swadaya masyarakat tetap masih diperlukan asalkan tidak menjadi trumpet kekuasaan atau pemilik modal. 
konstitusional sifatnya karena berdasarkan konstitusi UUD $1945 .^{16}$

Sesuai dengan ketentuan Pasal 3 UndangUndang Nomor 2 Tahun 2008 Tentang Partai Politik, antara lain ditegaskan bahwa Organisasi Partai politik harus didaftarkan ke kementerian Hukum dan hak Asassi Manusia, untuk menjadi badan hukum, dengan segala persyaratannya. Organisasi Partai Politik sebagai badan hukum, dapat bertindak sebagai subjek hukum, yang tentu dalam pelaksanaan tupoksinya adalah diwakili oleh para pengurus-pengurusnya. Dalam perkembangan ilmu pengetahun dan teknologi yang modern merupakan sebagai hasil kemajuan berfikir manusia, dan banyak sekali memberikan suatu pengaruh terhadap bentuk kejahatan korporasi, atau Tindak Pidana Korporasi baik dari segi kuantitas maupun dari bentuk segi kualitas.

Dari pemikiran di atas, suatu tindak pidana korupsi yang ada saat ini hampir tidak pernah dilakukan oleh perorangan, melainkan banyak dilakukan secara berkelompok dan terorganisasi secara rapih di perusahaan atau korporasi. Dalam konteks pencapaian tujuan korporasi, maka korporasi bertanggungjawab pula dalam pencapaian tujuan perlindungan sosial dan kesejahteraan sosial, sehingga ada keseimbangan antara hak dan kewajiban korporasi dalam menjalankan peranannya dalam proses pembangunan. Dengan semakin besarnya peranan korporasi dalam proses pembangunan, semakin besar pula perhatian terhadap perlindungan sosial antara lain dengan menggunakan sarana hukum pidana.
Undang-Undang Nomor 2 Tahun 2008 tentang Partai Politik serta undang-undang perubahannya, Undang-Undang Nomor 2 Tahun 2011 memang tidak memuat ketentuan yang spesifik mengatur ancaman sanksi terhadap partai politik terkait kasus korupsi kadernya. Namun dari total empat pasal dalam Bab Sanksi, terdapat beberapa pasal dan ayat yang sebenarnya bisa digunakan untuk menjerat partai politik terkait kasus korupsi. Sanksi administratif sampai pembubaran partai. Pasal-pasal dan ayat-ayat itu antara lain pasal 41, Pasal 47 ayat (5), Pasal 48 ayat (2), (3), (4), dan (5); pasal 50. Pasal 47 ayat (5) berbunyi, "Pelanggaran terhadap ketentuan sebagaimana dimaksud dalam Pasal 40 ayat (3) huruf e dikenai sanksi administratif yang ditetapkan oleh badan/lembaga yang bertugas untuk menjaga kehormatan dan martabat Partai Politik beserta anggotanya". Pasal 40 ayat (3) huruf e tentang larangan partai politik menggunakan fraksi di MPR, DPR, DPD, dan DPRD sebagai sumber pendanaan partai politik juga mengatur mengenai hal ini.

Dari rumusan Pasal 47 ayat (5), sebuah partai politik bisa saja dikenai sanksi administratif jika penegak hukum dapat membuktikan bahwa kader partai di parlemen melakukan korupsi dengan tujuan mendanai partai politiknya. Pasal 47 ayat (5) mensyaratkan bahwa penetapan sanksi dilakukan oleh badan/lembaga yang bertugas untuk menjaga kehormatan dan martabat Partai Politik beserta anggotanya. Implementasi pasal ini dapat dilaksanakan berdasarkan kewenangan Makhamah 
Konstitusi (MK). Berdasarkan pasal 24C ayat (1) UUD 1945 juncto pasal 10 ayat (1) huruf a s/d d Undang-Undang Nomor 24 Tahun 2003 juncto pasal 41, 48 dan 50 Undang-Undang Nomor 2 Tahun 2008 tentang Partai Politik juncto Undang-Undang Nomor 10 Tahun 2008 tentang Pemilu juncto Undang-Undang Nomor 8 Tahun 2011 tentang Makhamah Konstitusi, ditentukan bahwa MK memiliki 4 kewenangan konstitusional (constitutional authorities), yaitu: Menguji undang-undang terhadap UUD1945; memutus sengketa kewenangan antar lembaga Negara yang kewenangannya diberikan oleh UUD 1945; memutus pembubaran partai politik; dan memutus perselisihan tentang hasil pemilu. Selain itu, MK juga berfungsi sebagai derivasi dari kewenanngannya, yaitu sebagai the guardian of constitution, the interpreter of constitution, the guardian of democracy, the protector of citizens constitutional rights, the protector of human rights. ${ }^{17}$

\section{E. Penutup}

Bertitik tolak dari uraian tersebut diatas, maka pada bagian akhir dari penelitian ini, dikemukakan bagian penutup, terdiri dari kesimpulan dan saran/rekomendasi, sebagai berikut:

\section{Kesimpulan}

Pengaturan sistem pemilihan umum di Indonesia, selalu berubah-ubah dari masakemasa, sesuai dengan keinginan para politisi, para pembuat undang-undang. Berbagai ketentuan dalam peraturan perundang- undangan tentang pemilihan umum, mengadung berbagai multi tafsir, sehingga untuk kepastian hukum dapat diajukan gugatan dan kemudian dibatalkan oleh Mahkamah Konstitusi yang memiliki kewenangan untuk memutus sengketa kewenangan antar lembaga negara yang kewenangannya diberikan oleh UUD 1945; memutus pembubaran partai politik; dan memutus perselisihan tentang hasil pemilu.

Sebagai dampak negatif dari sistem pemilihan langsung di Indonesia, adalah semakin meningkatnya kejahatan korupsi yang melibatkan para politisi baik di lembaga legislatif, eksekutif maupun yudikatif akhir-akhir ini. Hal ini sangat berkaitan erat dengan efek negatif pilihan bangsa Indonesia dalam menentukan sistem pemilihan langsung, sebagaimana di atur dalam Pasal 2 Undang-Undang Nomor 10 tahun 2008 tentang Pemilu, yang membutuhkan biaya yang sangat besar, sehingga begitu terpilih dan berkuasa, terjebak melalukan tindakan yang bertentangan dengan hukum, manipulasi, korupsi, kolusi dan nepotisme (KKN), serta berbagai perbuatan tercela lainnya. Biaya politik yang begitu sangat besar, membuat para politisi hanya memikirkan bagaimana secepatnya menghasilkan uang untuk mengembalikan modal, membayar utang kepada para sponsor, dan menyetor ke partai politik pengusungnya.

\section{Saran/Rekomendasi}

Bertiti tolak dari uraian tersebut diatas, dapat dikemukakan beberapa saran/rekomendasi, antara lain sebagai berikut: Pertama, organisasi Partai Politik, semestinya harus mementingkan

17 Arief Hidayat, "Efektifitas Peran Mahkamah Konstitusi Sebagai Penjaga konstitusi (Perspektif Pembinaan Hukum dan Demokrasi)", (Makalah disampaikan dalam Continuing Legal Education (CLE)di Puslitbang BPHN,Kementerian Hukum dan HAM-RI, tanggal, 03 Mei 2013 di Jakarta), hlm. 2. 
kepentingan partai dibanding kepentingan orang-perorang. Dengantersangkutnyasejumlah petinggi partai terkait dugaan korupsi di Komisi Pemberantasan Korupsi (KPK), akhir-akhir ini, organisasi partai Politik harus dapat segera mengambil sikap. Mereka mau menyelamatkan partainya atau orang perorangnya. Kejahatan korporatif yang dilakukan oleh berbagai organisasi Partai politik, sangat berbahaya karena kejahatan terorganisasi, white collar crime, maka apabila kejahatan korporasi atau Tindak Pidana Korporasi ini tidak cepat ditangani serius, akan menimbulkan dampak besar di dalam pembangunan, terutama penegakan hukum.

Kedua, Terjadinya kejahatan korupsi dalam kaitannya dengan system pemilihan umum di Indonesia, karena adanya kerja sama antara politisi, penguasa ekonomi, dan birokrasi. Perputaran uang lebih banyak di ranah para penguasa ekonomi atau pengusaha. Oleh karena itu, untuk meminimalisasi tindak korupsi, diperlukan para pengusaha yang jujur dalam menjalankan profesinya, juga tidak menjalankan praktek korupsi dalam mempermudah urusan bisnisnya. Korupsi tidak akan pernah terjadi jika tidak ada niat dan kesempatan. Harus diyakini bahwa dengan berbagai hal yang telah dilakukan oleh segenap komponen bangsa ini dalam memberantas korupsi, suatu saat korupsi di negara ini akan dapat dikurangi secara siginifikan.

\section{DAFTAR PUSTAKA}

\section{Buku}

Badan Pembinaan Hukum Nasional, Pola Pikir dan Kerangka Sistem Hukum Nasional (Jakarta: BPHN, 1995/1996).

Bahar, Saafoedin, Pancasila Sebagai Ideologi Dalam Berbagai Bidang Kehidupan Bermasyarakat,
Berbangsa dan Bernegara (Jakarta: BP7 Pusat. 1993).

Breyer, Stephen, Analisa Hukum Dalam Tentang Efektifitas Penerapan hukum. Terjemahan Budiarto (Jakarta: Marthijn Nijhoff Press Netherland, 1995)

Djalil, Matori Abdul, Tuntutan Reformasi dan Penyelenggaraan Pemilu 1999 dalam Masa Transisi (Jakarta: KIPP, 1999).

Fisher, Roger dan Harold Berman, (Ed.) CeramahCeramah Tentang Hukum Amerika Serikat, Terjemahan. Gregory Churchill (Jakarta: PT Tata Nusa, 1996).

Haris, Syamsudin, Menggugat Pemilihan Umum Orde Baru (Jakarta: Yayasan Obor Indonesia, 1998).

Hikam, AS., Politik Kewarganegaraan Landasan Redemokratisasi di Indonesia (Jakarta: Penerbit Erlangga, 1999).

Kristiadi, J. (ed.), Menyelenggarakan Pemilu yang Luber dan Jurdil (Jakarta: CSIS, 1977).

Kusnardi, Moh \& Harmaily Ibrahim, Pengantar Hukum Tata Negara Indonesia (Jakarta: Penerbit Pusat Studi Hukum Tata Negara FHUI).

Lev, Daniel S., Hukum Dan Politik di Indonesia, Kesinambungan dan Perubahan, Cet I, (Jakarta: LP3S, 1990).

Liddle, R. William, Pemilu-pemilu Orde Baru; pasang Surut Kekuasaan Politik (Jakarta: LP3ES, 1992).

Lippman, Walter, Filsafat Publik, Terjemahan A. Rahman Zainuddin (Jakarta: Penerbit Yayasan Obor Indonesia, 1999).

Lubis, Solly, Pelaksanaan Pemilihan Umum di Indonesia dan Prospeknya (Jakarta: BPHN, 1992).

MD, Moh. Mahfud, Pergulatan Politik dan Hukum di Indonesia (Yogyakarta: Gama Media, 1999).

Negada, Politik Ekonomi Negara Berkembang (New York: New York University Press, 1998).

Rahardjo, Satjipto, Beberapa Pemikiran tentang Ancangan antar disiplin dalam Pembinaan Hukum Nasional (Bandung: Sinar Baru, 1985).

Rasti, Kemerdekaan Berbicara di Depan Umum (Jakarta: Ghalia, 1989).

Sardji, Hak Asasi Manusia Dalam Prospektif UUD 1945 (Jakarta: En \& Hill., 1991).

Sjamsuddin, Nazaruddin, Integrasi Politik di Indonesia (Jakarta: PT. Gramedia, 1989).

Soedjono, Penanaman Modal Asing di Negara Berkembang (Bandung: CV.Mandar Maju, 1999).

Soekanto, Soeryono dan Mustafa Abdullah, Sosiologi Hukum Dalam Masyarakat (Jakarta: Penerbit Rajawali Pers, 1982). 
Soekanto, Soerjono dan Sri Mamudji, Penelitian Hukum Normatif Suatu Tinjauan Singkat (Jakarta: CV.Rajawali, 1985).

Soekanto, Soerjono, Pengantar Penelitian Hukum (Jakarta: Universitas Indonesia, 1986).

Soemantri, Sri, Bunga Rampai Hukum Tata Negara (Bandung: Alumni, 1992).

Strong, C.F., Konstitusi-konstitusi Politik Modern: Kajian tentang Sejarah dan Bentuk-Bentuk Konstitusi Dunia, Diterjemahkan dari Modern Political Constitution: An Introduce tothe Comparative Study of Their History and Existing Form (Bandung: Nuansa Nusamedia, 2004).

Tim Nasional Reformasi Hukum, Transformasi Bangsa Menuju Masyarakat Madani (Jakarta: Sekretariat Wakil Presiden, 1999).

Tubagus Ronny Rahman Nitibaskara, Ketika Kejahatan Berdaulat: Sebuah Pendekatan Kriminologi, Hukum dan Sosiologi (Jakarta: Penerbit Peradaban. 2001).

Wahyono, Padmo. Masalah-Masalah Ketatanegaraan di Indonesia (Jakarta: Rajawali, 1984).

\section{Makalah / Artikel / Prosiding / Hasil Penelitian}

Budiardjo, Miriam, "Pemilu 1999 dan Pelajaran untuk Pemilu 2004" (makalah disampaikan pada Diskusi Meja Bundar dengan topik "Pemilu 1999: Evaluasi dan Reformasinya", diselenggarakan oleh Cetro (Center for Electoral Reform), Jakarta, 9 September 1999).
Hidayat, Arief. "Efektifitas Peran Mahkamah Konstitusi Sebagai Penjaga konstitusi (Perspektif Pembinaan Hukum dan Demokrasi)", (Makalah disampaikan dalam Continuing Legal Education (CLE)di Puslitbang BPHN,Kementerian Hukum dan HAM-RI, tanggal, 03 Mei 2013 di Jakarta).

Kristiadi, J., "Sistem Pemilu: Proporsional, Distrik atau Campuran" (makalah disampaikan pada Dialog Nasional tentang "Agenda Pemilu: Visi, Tantangan dan Prospek", Depok, 20-21 Juli 1998).

Subekti, Valina Singka, "Electoral Law Reform as a Prerequisite to Create Demokratization in Indonesia", (makalah disampaikan pada Seminar Towards Struktural Reforms for Democratization in Indonesia; Problems and Prospects, Jakarta, 1214 Agustus 1998).

\section{Internet}

Friastuti, Rini. Putusan MK: Pemilu Serentak Untuk Pemilu 2019, http://news.detik.com/ read/2014/ 01/ 23/ 151205/ 2476095 /10/ putusan-mk-pemilu-serentak- untuk- pemilu2019?ntprofil, (diakses 23 Januari 2014). 